\title{
F221Y mutation in hepatitis B virus reverse transcriptase is associated with hepatocellular carcinoma prognosis following liver resection
}

\author{
HUIMING LI ${ }^{1,2^{*}}$, JIAN'AN JIA ${ }^{1,3^{*}}$, MENGMENG WANG ${ }^{1}$, HUI WANG $^{1}$, \\ $\mathrm{XING} \mathrm{GU}^{1}$, MENG FANG ${ }^{1}$ and CHUNFANG GAO ${ }^{1}$ \\ ${ }^{1}$ Department of Laboratory Medicine, Eastern Hepatobiliary Surgery Hospital, Second Military Medical University, \\ Shanghai 200438; ${ }^{2}$ Fujian Medical University, First Clinical Medical School, Fuzhou, Fujian 350005; \\ ${ }^{3}$ Department of Laboratory Medicine, The 105th Hospital of PLA, Hefei, Anhui 230031, P.R. China
}

Received February 20, 2016; Accepted February 9, 2017

DOI: $10.3892 / \mathrm{mmr} .2017 .6362$

\begin{abstract}
Hepatitis B virus (HBV) reverse transcriptase (RT) is encoded by the polymerase gene in the reverse transcriptase region, which overlaps with the $\mathrm{S}$ gene. The association between mutations of HBV RT and the pathobiological features of hepatocellular carcinoma (HCC) remain to be elucidated. The present study aimed to examine mutations in this region of the HBV genome and its clinical significance. Briefly, HBV total DNA was extracted from 84 pairs of HCC tumor tissue and corresponding adjacent non-tumor tissue samples. The RT/S regions (nt130-1161) were amplified and sequenced using the Sanger method, and associations between RT mutations and the clinical characteristics of patients with HCC were analyzed. Finally, 27 and 29 mutations with frequencies $>5 \%$ were identified in the RT and S regions, respectively. The rtF221Y variation and a tumor size $>8 \mathrm{~cm}$ were found to be independent risk factors for the postoperative recurrence of $\mathrm{HCC}$, with hazard ratios of 2.345 (95\% CI, 1.391-3.953; $\mathrm{P}=0.001)$ and 1.838 (95\% CI, 1.069-3.161; $\mathrm{P}=0.028$ ), respectively. $\mathrm{rtF} 221 \mathrm{Y}$ was also an independent risk factor for poor overall survival
\end{abstract}

Correspondence to: Professor Chunfang Gao, Department of Laboratory Medicine, Eastern Hepatobiliary Surgery Hospital, Second Military Medical University, 225 Changhai Road, Shanghai 200438, P.R. China

E-mail: gaocf1115@163.com

*Contributed equally

Abbreviations: $\mathrm{HBV}$, hepatitis B virus; $\mathrm{HCC}$, hepatocellular carcinoma; RT, reverse transcriptase; tDNA, HBV total DNA; cccDNA, covalently closed circular DNA; TT, tumor tissue; ANTT, adjacent non-tumor tissue; NA, nucleos(t)ide analogue; ADV, adefovir dipivoxil; OS, overall survival; DFS, disease-free survival; MHR, major hydrophilic region; WT, wild-type; MT, mutant type.

Key words: F221Y, hepatitis B virus, mutation, reverse transcriptase, hepatocellular carcinoma, prognosis rates $(\mathrm{HR}=2.557 ; 95 \% \mathrm{CI}, 1.344-4.866 ; \mathrm{P}=0.004)$. The mutation of $\mathrm{R} 122 \mathrm{~K}$ in the HBV S protein was closely associated with tumor recurrence $(\mathrm{P}<0.001)$. As a result, $\mathrm{rtF} 221 \mathrm{Y}$ was identified as a risk factor for poor prognosis and may be a potential viral marker for predicting prognosis in HCC.

\section{Introduction}

Hepatitis B virus (HBV) infection is one of the major etiological factors of HCC in China (1). Almost 360,000,000 individuals are chronic HBV carriers worldwide (2). HBV infection can lead to liver diseases, including hepatitis, liver cirrhosis and hepatocellular carcinoma (HCC) (3). The HBV genome has a partially double stranded circular structure, consisting of four overlapping open reading frames (ORFs) (4) encoding the virus polymerase, $S$ protein, $X$ protein and core protein, respectively. The ORF of polymerase contains four regions: A carboxy terminal region (nt2307-2840), spacer region (nt2841-129), reverse transcriptase (RT) region (nt130-1161) and an RNase H region (nt1129-1621) (5), of which the RT region is crucial for HBV replication. Several mutations occur in the HBV genome due to deficiency in the proofreading function in RT and HBV replication through RNA-intermediated reverse transcription. Therefore, in the course of HBV infection, mutations continuously accumulate, and a number of these mutations may be used as viral markers for evaluating the development and prognosis of $\mathrm{HBV}$-associated HCC.

Numerous studies in previous decades have focused on the association between HBV mutations, including point mutations, deletions and structure variation, and the risk of HCC. It has been shown that nucleotide mutations in the $\mathrm{S}$ gene and pre $\mathrm{C} / \mathrm{C}$ gene are closely associated with increasing risks of HCC (6-9). In the basal core promoter/enhancer II region, A1762T/G1764A has been found to be significantly associated with HCC (10-12). Increasing studies are focusing on the association between HBV gene variation and the prognosis with HCC. Yeh et al (13) reported that the presence of the A1762T/G1764A mutation in liver tissue within the BCP was an independent predictor for disease-free survival (DFS) and overall survival (OS) rates in HCC. A pre-S deletion located between codons 107 and 141 was 
found to be associated with poorer postoperative prognosis, and $\mathrm{Su}$ et al (14) showed that the pre-S deletion was crucial for post-operative tumor recurrence. However, studies investigating mutations in RT associated with the HCC prognosis are limited.

In the present study, HBV DNA was extracted from liver tissues of patients with HCC, and viral quasispecies within the $\mathrm{RT} / \mathrm{S}$ region (RT overlapped with the $\mathrm{S}$ gene) were analyzed using Sanger sequencing. Cox proportional hazard model analysis was used to investigate the association between variations in the HBV RT/S region and the prognosis of HCC.

\section{Materials and methods}

Patients and samples. A total of 84 patients with HCC were recruited between March 2007 and May 2009, who received complete surgical resection at the Eastern Hepatobiliary Surgery Hospital (Shanghai, China). Serum samples, tumor tissue (TT) and paired adjacent non-tumor tissue (ANTT) samples were collected. Written informed consent was obtained from all patients. The present study was approved by the Ethics Committee of Human Resources at the Second Military Medical University (Shanghai, China).

Patients were included in the cohort for examination if they fulfilled following inclusion criteria: i) serum hepatitis B surface antigen (HBsAg)-positive for at least 6 months; ii) HBV DNA levels $>1,000 \mathrm{IU} / \mathrm{ml}$; iii) nucleos(t)ide analogue (NA) naïve prior to surgical resection. The exclusion criteria included hepatitis $\mathrm{C}$ virus or human immunodeficiency virus co-infection, or a history of liver transplantation, autoimmune liver diseases, metastatic liver cancer, other malignancies, drug-associated liver diseases, alcoholic hepatitis or other causes of chronic liver disease diagnosed prior to enrollment.

$H B V$ nucleic acid extraction and polymerase chain reaction (PCR) amplification. HBV genomes were extracted from frozen TTs and ANTTs with a QIAamp DNA Mini kit (Qiagen GmbH, Hilden, Germany), according to the manufacturer's protocol. Due to the limitation of sequencing length, the RT region was amplified as two overlapping segments, respectively. The primers for the first segment were as follows: Forward 5'-CTG CTGGTGGCTCCAGTTC-3' (nucleotides 57-75) and reverse 5'-TGGCTCAGTTTACTAGTGCCA-3' (nucleotides 668-688). The primers for the second segment were as follows: Forward 5'-TCAGTCCGT TTC TCCTGGCTCAG-3' (nucleotides 653-675) and reverse 5'-GAGTTCCGCAGTATGGATCG-3' (nucleotides 1,281-1,262). The RT segments were amplified with Phusion High-Fidelity DNA polymerase (Thermo Fisher Scientific, Inc., Waltham, MA, USA). The final composition of $20 \mu 1$ PCR mixtures contained $5 \mu 1$ DNA template, $0.5 \mu 1$ Phusion High-Fidelity DNA polymerase, $4 \mu 1$ XX Phusion HF buffer, $0.5 \mu \mathrm{l} 10 \mathrm{mM}$ dNTPs, $1 \mu \mathrm{l}$ forward primer $(1 \mu \mathrm{M}), 1 \mu \mathrm{l}$ reverse primer $(1 \mu \mathrm{M})$ and $8 \mu \mathrm{l}$ DNase-Free water. The RT segments were amplified with the following thermocycling conditions: $95^{\circ} \mathrm{C}$ for $5 \mathrm{~min}$ followed by 35 cycles of $98^{\circ} \mathrm{C}$ for $30 \mathrm{sec}, 57^{\circ} \mathrm{C}$ for $30 \mathrm{sec}$ and extension at $72^{\circ} \mathrm{C}$ for $1 \mathrm{~min}$. The mixtures were subjected to further extension at $72^{\circ} \mathrm{C}$ for $10 \mathrm{~min}$. The TaqMan probes for covalently closed circular (ccc) DNA and intrahepatic HBV total DNA (tDNA) quantification were FAM-ATCTGC CGGACCGTGTGC-TAMARA and FAM-CTCACCAACCTC CTGTCCTCCA-TAMARA, respectively.
Table I. Clinical characteristics of patients with HBV-associated hepatocellular carcinoma.

\begin{tabular}{|c|c|c|}
\hline Characteristic & Cohort $(n=84)$ & P-value \\
\hline \multicolumn{3}{|l|}{ Gender } \\
\hline Male & $72(86 \%)$ & \\
\hline Female & $12(14 \%)$ & \\
\hline Age (years) & $50(28-70)$ & \\
\hline $\operatorname{AFP}(n g / m l)$ & $1,067(1.5->1,210)$ & \\
\hline TBIL $(\mu \mathrm{mol} / \mathrm{l})$ & $14.7(7.1-50.5)$ & \\
\hline $\mathrm{DBIL}(\mu \mathrm{mol} / \mathrm{l})$ & $5.4(1.7-18.4)$ & \\
\hline ALT (U/l) & $49(21-1,067)$ & \\
\hline AST (U/l) & $51(22-1041)$ & \\
\hline Serum HBV DNA $\left(\log _{10} \mathrm{IU} / \mathrm{ml}\right)$ & $5.2(3.0-7.6)$ & \\
\hline HBV tDNA ( $\log _{10}$ copies $/ 10^{6}$ cells $)$ & & 0.029 \\
\hline TT & $6.6 \pm 1.2$ & \\
\hline ANTT & $7.0 \pm 0.9$ & \\
\hline cccDNA ( $\log _{10}$ copies $/ 10^{6}$ cells $)$ & & 0.544 \\
\hline $\mathrm{TT}$ & $4.9 \pm 1.4$ & \\
\hline ANTT & $5.0 \pm 1.0$ & \\
\hline $\mathrm{HBsAg}\left(\log _{10} \mathrm{IU} / \mathrm{ml}\right)$ & $3.1(0.32-4.11)$ & \\
\hline Tumor size (cm) & $8.0(1.1-25.0)$ & \\
\hline \multicolumn{3}{|l|}{$\mathrm{HBeAg}$} \\
\hline Positive & $40(48 \%)$ & \\
\hline Negative & $44(52 \%)$ & \\
\hline \multicolumn{3}{|l|}{ HBV genotype } \\
\hline $\mathrm{B}$ & $22(26 \%)$ & \\
\hline $\mathrm{C}$ & $62(74 \%)$ & \\
\hline \multicolumn{3}{|l|}{ Ascites } \\
\hline Yes & $13(15 \%)$ & \\
\hline No & $67(80 \%)$ & \\
\hline \multicolumn{3}{|l|}{ Tumor number } \\
\hline Single & $59(70 \%)$ & \\
\hline Multiple & $22(26 \%)$ & \\
\hline \multicolumn{3}{|l|}{ Cirrhosis } \\
\hline Present & $72(86 \%)$ & \\
\hline Absent & $12(14 \%)$ & \\
\hline \multicolumn{3}{|l|}{ Capsule } \\
\hline Complete & $23(27 \%)$ & \\
\hline Incomplete & $47(56 \%)$ & \\
\hline \multicolumn{3}{|l|}{ TNM stage } \\
\hline I-II & $49(58 \%)$ & \\
\hline III-IV & $23(27 \%)$ & \\
\hline
\end{tabular}

HBV, hepatitis B virus; HbsAg, hepatitis B surface antigen; AFP, $\alpha$-fetoprotein; TBIL, total bilirubin; DBIL, direct bilirubin; ALT, alanine aminotransferase; AST, aspartate aminotransferase; tDNA, total DNA; cccDNA, covalently closed circular DNA; TT, tumor tissue; ANTT, adjacent non-tumor tissue; $\mathrm{HBeAg}$, hepatitis $\mathrm{B}$ e antigen; TNM, tumor-node-metastasis.

Sanger sequencing and sequence alignment. The products of the RT region segmented PCR amplification were gel purified 
Table II. Univariate and multivariate analyses of clinicopathologial and virological characteristic for DFS and OS in patients with HBV-associated hepatocellular carcinoma.

\begin{tabular}{|c|c|c|c|c|c|c|c|c|}
\hline \multirow[b]{3}{*}{ Characteristic } & \multicolumn{4}{|c|}{ DFS } & \multicolumn{4}{|c|}{ OS } \\
\hline & \multirow{2}{*}{$\frac{\text { Univariate }}{\text { P-value }}$} & \multicolumn{3}{|c|}{ Multivariate } & \multirow{2}{*}{$\frac{\text { Univariate }}{\text { P-value }}$} & \multicolumn{3}{|c|}{ Multivariate } \\
\hline & & HR & $(95 \% \mathrm{CI})$ & P-value & & HR & $(95 \% \mathrm{CI})$ & P-value \\
\hline Age $>50$ years & 0.717 & & & & 0.985 & & & \\
\hline Gender (male) & 0.680 & & & & 0.952 & & & \\
\hline $\mathrm{AFP}>400 \mathrm{ng} / \mathrm{ml}$ & 0.736 & & & & 0.735 & & & \\
\hline $\mathrm{ALT}>40 \mathrm{U} / 1$ & 0.274 & & & & 0.475 & & & \\
\hline Tumor size $>8 \mathrm{~cm}$ & $<0.001$ & 2.345 & $1.391-3.953$ & 0.001 & 0.688 & & & \\
\hline HBV DNA $\left(\log _{10} \mathrm{IU} / \mathrm{ml}\right)$ & 0.497 & & & & 0.375 & & & \\
\hline $\begin{array}{l}\text { ANTT HBV tDNA } \\
\left(\log _{10} \text { copies } / 10^{6} \text { cells }\right)\end{array}$ & 0.673 & & & & 0.452 & & & \\
\hline $\begin{array}{l}\text { ANTT HBV cccDNA } \\
\left(\log _{10} \text { copies } / 10^{6} \text { cells }\right)\end{array}$ & 0.892 & & & & 0.695 & & & \\
\hline $\mathrm{N} 13 \mathrm{R} / \mathrm{S}$ & 0.024 & & & & 0.130 & & & \\
\hline $\mathrm{I} 16 \mathrm{~T}$ & 0.002 & & & & 0.015 & & & \\
\hline S53N & 0.002 & & & & 0.020 & & & \\
\hline $\mathrm{H} 55 \mathrm{R} / \mathrm{Q} / \mathrm{K}$ & 0.509 & & & & 0.056 & & & \\
\hline I91L & $<0.001$ & & & & 0.017 & & & \\
\hline P109S & 0.419 & & & & 0.612 & & & \\
\hline $\mathrm{T} 118 \mathrm{~N}$ & 0.118 & & & & 0.321 & & & \\
\hline N121I & 0.023 & & & & 0.084 & & & \\
\hline $\mathrm{Y} 124 \mathrm{~N} / \mathrm{H}$ & 0.004 & & & & 0.160 & & & \\
\hline G127R & 0.005 & & & & 0.084 & & & \\
\hline N131D & 0.001 & & & & 0.058 & & & \\
\hline $\mathrm{D} 134 \mathrm{~N} / \mathrm{E}$ & 0.994 & & & & 0.405 & & & \\
\hline N139K & 0.211 & & & & 0.197 & & & \\
\hline L145M & 0.190 & & & & 0.119 & & & \\
\hline F151Y & 0.003 & & & & 0.033 & & & \\
\hline F221Y & $<0.001$ & 1.838 & $1.069-3.161$ & 0.028 & 0.003 & 2.557 & $1.344-4.866$ & 0.004 \\
\hline $\mathrm{T} 222 \mathrm{~A}$ & 0.003 & & & & 0.033 & & & \\
\hline S223A & 0.210 & & & & 0.311 & & & \\
\hline $\mathrm{I} 224 \mathrm{~V}$ & 0.784 & & & & 0.638 & & & \\
\hline $\mathrm{N} 238 \mathrm{H}$ & 0.272 & & & & 0.543 & & & \\
\hline $\mathrm{S} 256 \mathrm{C}$ & 0.959 & & & & 0.092 & & & \\
\hline Q267L & 0.146 & & & & 0.679 & & & \\
\hline L269I & 0.012 & & & & 0.272 & & & \\
\hline R280P & 0.077 & & & & 0.097 & & & \\
\hline S317A & 0.027 & & & & 0.056 & & & \\
\hline C332S/R & 0.007 & & & & 0.085 & & & \\
\hline K333Q & 0.002 & & & & 0.154 & & & \\
\hline
\end{tabular}

HBV, hepatitis B virus; DFS, disease-free survival; OS, overall survival; CI, confidence interval; ANTT, adjacent non-tumor tissue; tDNA, total DNA; cccDNA, covalently closed circular DNA; AFP, $\alpha$-fetoprotein; ALT, alanine aminotransferase.

and sequenced using an ABI PRISM BigDye sequencing kit on an ABI 3500 genetic analyzer (Applied Biosystens; Thermo Fisher Scientific, Inc.). HBV genotypes were identified using an online genotyping tool (http://www.ncbi.nlm.nih.gov/projects/genotyping/formpage.cgi). The sequences from each of the samples were compared with the RT sequence in the NCBI database (HBVgp1; NC_003977.2), which was performed using DNAMAN software (version 4.0; Lynnon Corporation, Pointe-Claire, QC, Canada).

Statistical analysis. Mutations between TT and ANTT were analyzed using the $\chi^{2}$ test. Forward stepwise multivariate regression analysis was performed to obtain the hazard ratios of potential risk factors for HCC prognosis. Matched 

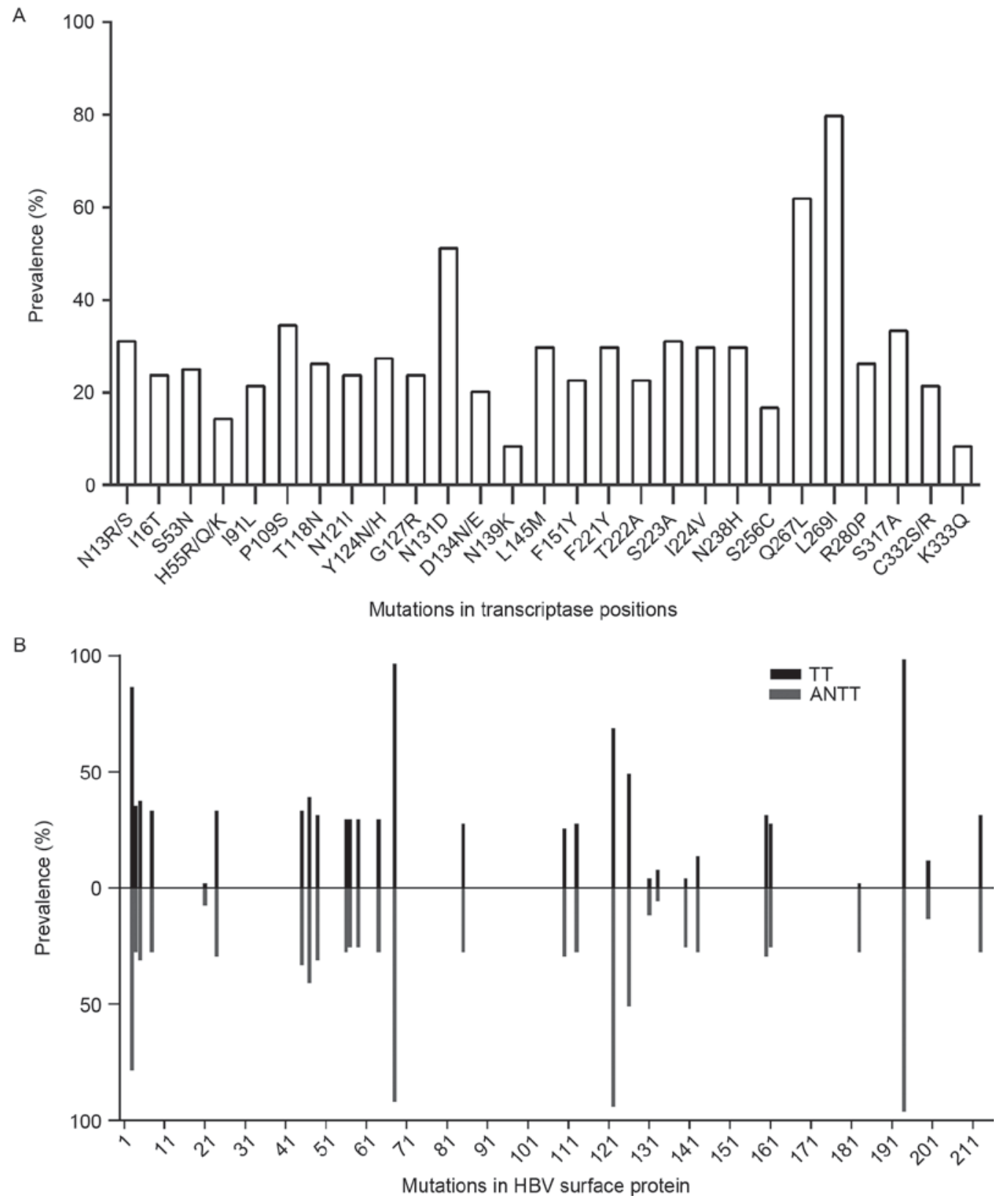

Figure 1. Amino acid mutations in reverse transcriptase and HBsAg. (A) 27 amino acid substitutions within reverse transcriptase. (B) Overall distributions of amino acid mutations and their relative frequencies within the HBV HBsAg. HBV, hepatitis B virus; HBsAg, hepatitis B surface antigen; TT, tumor tissue; ANTT, adjacent non-tumor tissue.

clinicopathological characteristics were subjected to stratified analysis. $\mathrm{P}<0.05$ was considered to indicate a statistically significant difference. All statistical analyses were performed on SPSS software (version 18.0; SPSS, Inc., Chicago, IL, USA).

\section{Results}

Patient characteristics. The baseline characteristics of the 84 patients included in the present study are presented in Table I. The cohort, comprised of 72 (86\%) male subjects, had a median age of 50 years, and $74 \%$ were infected with HBV genotype C. Over half of the patients (58\%) were histologically diagnosed with early stage tumors (tumor-node-metastasis stages I-II). In addition, the median duration of HCC recurrence was 10.0 months (range 0.43-50.9 months).
Association between intrahepatic $H B V D N A$ and serum $H B V D N A$. The levels of HBV tDNA in the ANTTs were higher, compared with those in the TTs $(7.0 \pm 0.9$, vs. $6.6 \pm 1.2$ $\log _{10}$ copies $/ 10^{6}$ cells; $P=0.029$; Table I). Serum HBV DNA was moderately correlated with ANTT tDNA $(r=0.419 ; \mathrm{P}<0.001)$ and cccDNA $(r=0.370 ; \mathrm{P}<0.001)$, but not with TT tDNA $(\mathrm{r}=0.154 ; \mathrm{P}=0.166)$ or $\mathrm{cccDNA}(\mathrm{r}=0.123 ; \mathrm{P}=0.281)$. These results suggested that serum HBV DNA may derive from ANTTs, rather than TTs, therefore, serum HBV DNA levels may not reflect the real level of HBV DNA in TTs.

Characteristics of amino acid mutations in RT and HBsAg. According to the criteria of 5\% frequency, a total of 27 amino acid mutations in the RT domain were included (Fig. 1A). The majority of these mutations occurred with a frequency of 
Table III. Comparison of clinical characteristics of patients with and without the rtF221Y mutation.

\begin{tabular}{|c|c|c|c|}
\hline Characteristic & $\operatorname{MT}(n=25)$ & WT $(n=59)$ & P-value \\
\hline Age (years) & $49.2 \pm 8.5$ & $49.2 \pm 9.8$ & 0.748 \\
\hline $\operatorname{ALT}(\mathrm{U} / \mathrm{l})$ & $50(21.2-360.5)$ & $49(21.4-1,067.5)$ & 0.773 \\
\hline DBIL $(\mu \mathrm{mol} / \mathrm{l})$ & $4.9 \pm 1.8$ & $6.4 \pm 3.0$ & 0.021 \\
\hline $\operatorname{AFP}(\mathrm{ng} / \mathrm{ml})$ & $1,210(39.7-1,210)$ & $496(10-1,210)$ & 0.048 \\
\hline CREA $(\mu \mathrm{mol} / 1)$ & $71.5 \pm 11.1$ & $65.6 \pm 9.5$ & 0.018 \\
\hline Serum HBV DNA $\left(\log _{10} \mathrm{IU} / \mathrm{ml}\right)$ & $5.1 \pm 1.3$ & $5.3 \pm 1.0$ & 0.525 \\
\hline ANTT tDNA $\left(\log _{10}\right.$ copies $/ 10^{6}$ cells $)$ & $6.8 \pm 1.0$ & $7.0 \pm 0.9$ & 0.461 \\
\hline ANTT cccDNA( $\log _{10}$ copies $/ 10^{6}$ cells $)$ & $5.3 \pm 0.9$ & $4.8 \pm 1.1$ & 0.090 \\
\hline \multicolumn{4}{|l|}{ Tumor diameter $(\mathrm{cm})$} \\
\hline$\leq 8$ & 4 & 24 & \multirow[t]{2}{*}{0.001} \\
\hline$>8$ & 18 & 35 & \\
\hline \multicolumn{4}{|l|}{ Ascites } \\
\hline Yes & 3 & 10 & \multirow[t]{2}{*}{0.487} \\
\hline No & 22 & 45 & \\
\hline \multicolumn{4}{|l|}{ Capsule } \\
\hline Complete & 15 & 32 & \multirow[t]{2}{*}{0.994} \\
\hline Incomplete & 8 & 17 & \\
\hline \multicolumn{4}{|l|}{ Tumor number } \\
\hline Single & 14 & 45 & \multirow[t]{2}{*}{0.255} \\
\hline Multiple & 8 & 24 & \\
\hline
\end{tabular}

Data are presented as the mean \pm standard deviation or median (range). MT, rtY221 mutant type; WT, rtF221, wild-type; ALT, alanine aminotransferase; DBIL, direct bilirubin; AFP, $\alpha$-fetoprotein; CREA, creatinine; HBV, hepatitis B virus; ANTT, adjacent non-tumor tissue; tDNA, total DNA; cccDNA, covalently closed circular DNA.

$>20 \%$, particularly rtQ267 L and rtL269I, which had frequencies $>50 \%$. Common NA resistance mutations, including rtI169T, rtA181T/V, rtT184A/C/F/G/I/L/M/S, rtA194T, rtS202C/G/I, rtM204I/V/S, rtN236T, rtM250I/L/V, rtV173 L and rtL80I/V were not detected during sequence alignment. The substitutions of rtS53N, rtI91L, rtF221Y and rtN238H detected were putative NA-resistance mutations. The pretreatment mutations, $\mathrm{rtY} 124 \mathrm{~N} / \mathrm{H}$ and $\mathrm{rtN139K}$, were also found in the cohort. As the HBV S gene overlaps with the RT gene, the $\mathrm{S}$ gene originating from 51 pairs of TTs and ANTTs were analyzed, and 29 amino acid mutations within HBsAg met the $5 \%$ frequency inclusion criteria (Fig. 1B). The frequencies of sA194V, sT68I, sR122K, sS3N and sI126T were $>50 \%$, and 10 amino acid mutations were located in the major hydrophilic region (MHR; aa99-169) of HBsAg. No significant differences were found in HBsAg mutations between TTs and ANTTs, with the exception of three mutations, sR122 K ( $\mathrm{P}=0.004)$, sT140S $(\mathrm{P}=0.001)$ and sF183V $(\mathrm{P}=0.001)$, which occurred more frequently in ANTTs.

Mutations associated with the prognosis of HCC. The Cox proportional hazard model was used to analyze the association between clinicopathological and virological factors associated with DFS and OS following surgical resection of HBV-associated HCC (Table II). Tumor sizes $>8 \mathrm{~cm}$ $(\mathrm{HR}=2.345 ; \mathrm{P}=0.001)$ and $\mathrm{rtF} 221 \mathrm{Y}(\mathrm{HR}=1.838 ; \mathrm{P}=0.028)$ were associated with shorter DFS. rtF221Y $(\mathrm{HR}=2.557 ; \mathrm{P}=0.004)$ was also found to be an independent risk factor for OS. Kaplan-Meier survival analysis indicated that rtF221Y was significantly associated with poorer DFS $(\mathrm{P}=0.0027)$ and $\mathrm{OS}$ $(\mathrm{P}<0.001$; Fig. 2A and B). The DFS and OS rates were significantly shorter in those with the rtF221Y mutation, compared with those with the wild-type amino acid. In addition, when Kaplan-Meier survival analysis and log-rank tests were used to compare survival probability, it was found that the $\mathrm{HBs} \mathrm{Ag}$ R122 K mutation in the TT was closely associated with tumor recurrence $(\mathrm{P}<0.001$; Fig. $2 \mathrm{C})$ and patients with the $\mathrm{RR} 122 \mathrm{~K}$ mutation had a higher rate of recurrence $(\mathrm{P}=0.002)$, which was determined using the $\chi^{2}$ test.

Association between HBV mutations and the clinical characteristics of patients with HCC. The levels of $\alpha$-fetoprotein (AFP) in patients with the F221Y mutation were higher, compared with those without the mutation $(\mathrm{P}=0.048)$. In addition, patients harboring the F221Y mutation had larger tumor sizes, compared with patients without the F221Y mutation ( $\mathrm{P}=0.001$; Table III). No significant differences in age, alanine aminotransferase (ALT), aspartate aminotransferase, $\gamma$-glutamyltransferase, serum HBV DNA levels or tumor numbers were found between the patients with or without theF221Y mutation.

Due to the negative relevance between HBsAg mutations in ANTTs with clinicopathological characteristics, amino acid substitutions within HBsAg in TTs were subjected to stratified analysis (Table IV). The results revealed that the 
Table IV. Association between TT HBsAg mutations and patient characteristics.

\begin{tabular}{|c|c|c|c|c|c|c|c|c|c|}
\hline \multirow[b]{2}{*}{ Characteristic } & \multicolumn{3}{|c|}{$\mathrm{sS} 3 \mathrm{~N}$} & \multicolumn{3}{|c|}{ sR122K } & \multicolumn{3}{|c|}{ sI126T } \\
\hline & WT n=7 & MT n=44 & P-value & WT $n=16$ & MT $n=35$ & P-value & WT $n=26$ & MT n=25 & $\mathrm{P}$-value \\
\hline Age (years) & 50.4 & 49 & 0.710 & 51.1 & 48.3 & 0.296 & 50.3 & 48.1 & 0.392 \\
\hline \multicolumn{10}{|l|}{ Gender } \\
\hline Male & 1 & 2 & 0.364 & 15 & 30 & 0.999 & 25 & 23 & 0.610 \\
\hline Female & 6 & 42 & & 1 & 2 & & 1 & 2 & \\
\hline ALT (U/l) & 148 & 65 & 0.925 & 97.1 & 70.2 & 0.948 & 95 & 58 & 0.105 \\
\hline $\operatorname{AFP}(\mathrm{ng} / \mathrm{ml})$ & 866 & 730 & 0.620 & 767 & 772 & 0.736 & 570 & 935 & 0.007 \\
\hline HBsAg (S/CO) & 2,696 & 1,434 & 0.378 & 1,809 & 1,455 & 0.543 & 2,006 & 1,134 & 0.162 \\
\hline $\begin{array}{l}\text { Serum DNA } \\
\left(\log _{10} \mathrm{IU} / \mathrm{ml}\right)\end{array}$ & 4.86 & 5.46 & 0.201 & 5.07 & 5.51 & 0.166 & 5.53 & 5.24 & 0.354 \\
\hline $\begin{array}{l}\text { HBV tDNA } \\
\left(\log _{10} \text { copies } / 10^{6} \text { cells }\right)\end{array}$ & 6.56 & 7.02 & 0.215 & 7.1 & 6.9 & 0.428 & 7.12 & 6.79 & 0.204 \\
\hline $\begin{array}{l}\operatorname{cccDNA} \\
\left(\log _{10} \text { copies } / 10^{6} \text { cells }\right)\end{array}$ & 3.96 & 5.09 & 0.004 & 4.8 & 4.9 & 0.687 & 4.88 & 5 & 0.675 \\
\hline Tumor size $(\mathrm{cm})$ & 9.7 & 8.4 & 0.565 & 5.9 & 9.7 & 0.017 & 7.12 & 10.04 & 0.049 \\
\hline \multicolumn{10}{|l|}{ Recurrence } \\
\hline Yes & 7 & 33 & 0.323 & 8 & 32 & 0.002 & 21 & 19 & 0.679 \\
\hline No & 0 & 11 & & 8 & 3 & & 5 & 6 & \\
\hline \multicolumn{10}{|l|}{ Cirrhosis } \\
\hline Present & 6 & 39 & 1.000 & 13 & 31 & 0.999 & 23 & 22 & 1.000 \\
\hline Absent & 0 & 5 & & 1 & 4 & & 2 & 3 & \\
\hline \multicolumn{10}{|l|}{ Tumor number } \\
\hline Single & 4 & 33 & 0.643 & 10 & 27 & 0.493 & 18 & 19 & 0.747 \\
\hline Multiple & 2 & 11 & & 5 & 8 & & 7 & 6 & \\
\hline \multicolumn{10}{|l|}{ Capsule } \\
\hline Complete & 3 & 26 & 1.000 & 4 & 25 & 0.019 & 14 & 15 & 0.936 \\
\hline Incomplete & 2 & 15 & & 8 & 9 & & 8 & 9 & \\
\hline \multicolumn{10}{|l|}{ TNM stage } \\
\hline I-II & 5 & 29 & 0.573 & 9 & 25 & 0.411 & 16 & 18 & 0.734 \\
\hline III-IV & 0 & 10 & & 1 & 9 & & 4 & 6 & \\
\hline
\end{tabular}

Continuous variables are presented as the mean \pm standard deviation or median (range). MT, mutant type; WT, wild-type; ALT, alanine aminotransferase; DBIL, direct bilirubin; AFP, $\alpha$-fetoprotein; CREA, creatinine; HBV, hepatitis B virus; TT, tumor tissue; tDNA, total DNA; cccDNA, covalently closed circular DNA; TNM, tumor-node-metastasis.

occurrence of the $\mathrm{sS} 3 \mathrm{~N}$ mutation was associated with higher TT cccDNA levels (3.96 \pm 0.7 , vs. $5.09 \pm 1.0 \log _{10}$ copies $/ 10^{6}$ cells; $\mathrm{P}=0.004)$. In addition, patients with sI126T had higher AFP levels, compared with those with wild-type HBsAg $(\mathrm{P}=0.007)$. Patients with sR122 K or sI126T had larger tumor sizes ( $\mathrm{P}=0.017$ and $\mathrm{P}=0.049$, respectively). However, no associations were found between HBsAg mutations in the ANTTs and the clinicopathological features.

\section{Discussion}

Although several studies have focused on the association between HBV variation and HCC, the majority of these have been performed using serum samples (11). Previous data have reported that serum HBV DNA shows moderate correlation with ANTT viral DNA, but no correlation with that of TT, which suggests that the presence of variants in serum HBV DNA may not reveal the actual status in the liver. Therefore, resected tissue specimens may have preponderance when designing investigations. Furthermore, the quantitative results of HBV tDNA and cccDNA from the liver tissues in the present study suggested that the levels of tDNAs in ANTT were significantly higher, compared with those in paired TT samples $(\mathrm{P}=0.029)$. The microenvironment in ANTT may be more suitable for HBV replication, and viruses in TT may have deficient replication activity due to an unfavorable microenvironment. Therefore, numerous missense mutations are likely to accumulate during the replication of HBV in the ANTT. HBV DNA in TT is more likely to integrate with the hepatocyte genome, which may also contribute to the lower level of replication of viral DNA (15). $\mathrm{HBV}$ integration can be detected at any stage of HBV infection and it is reasonable to suggest that fewer mutations in the 
A

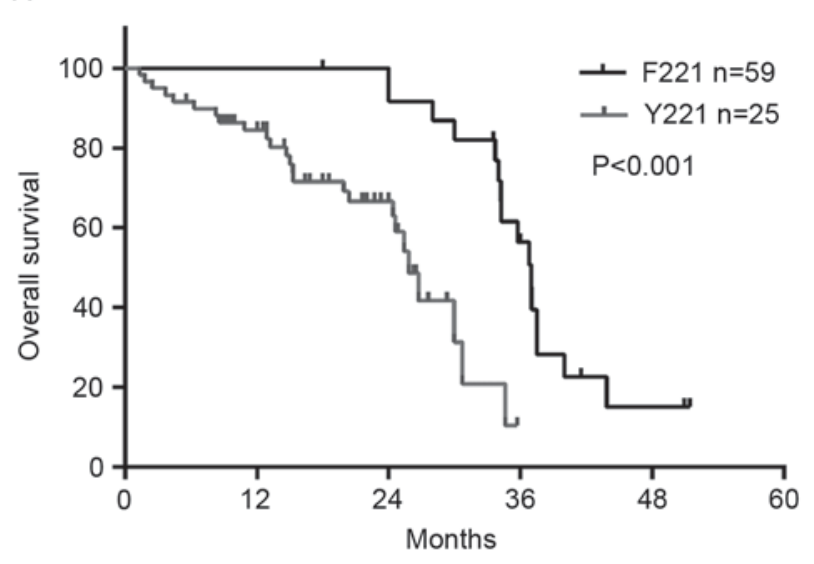

B

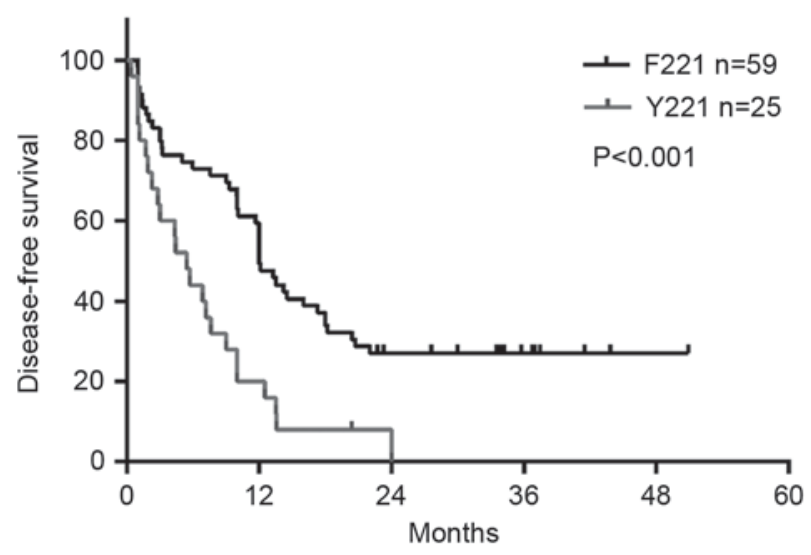

C

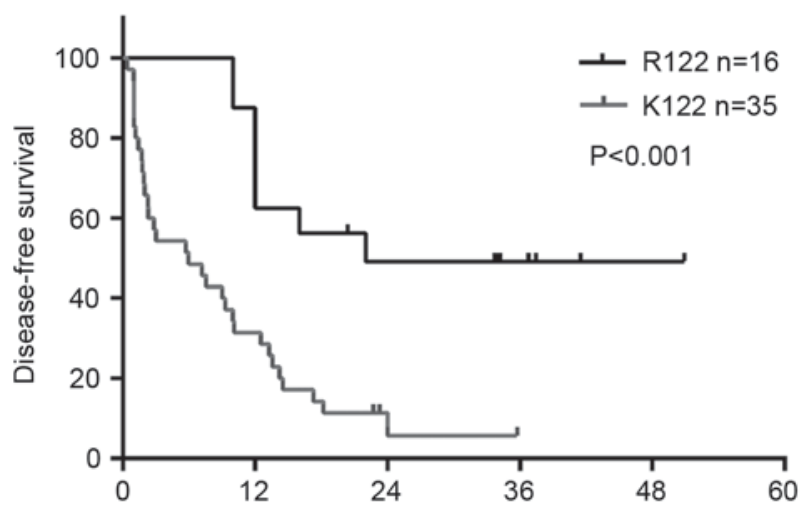

Figure 2. Association between survival and mutations. Comparison of postoperative (A) overall survival and (B) disease-free survival between patients with or without $\mathrm{rtF} 221 \mathrm{Y}$. (C) Comparison of disease-free survival between two group characterized by sR122 and sK122. The log-rank test was used to compare the survival curves between groups.

integrated form of the HBV genome occur in TT, compared with the replicative form of the HBV genome in ANTT $(16,17)$. When the distribution of HBV mutations between the TT and ANTT samples were compared in the present study, there were only nuance were detected. As a result, gene variations in the HBV genome derived from ANTT may more suitable for investigations on the effect of HBV mutations on HCC.
Several studies have indicated that mutations in the S, C and $\mathrm{X}$ genes of the HBV genome are associated with a high risk of HCC $(18,19)$, however, there are few reports on mutations in the RT region of the HBV genome, particularly in TTs and ANTTs, and its effect on development and prognosis of HCC. The present study focused on the genetic diversity in RT sequences isolated from liver tissues. When the alignment was completed, 27 mutations were obtained when the occurrence rate threshold was set as 5\%. In addition, there was minimal observation of common NAs resistance mutations in sequence alignment, including L80I/V, I169T, V173L, A181T/V, T184A/ C/F/G/I/L/M/S, A194T, S202C/G/I, M204I/V/S, N236T and $\mathrm{M} 250 \mathrm{I} / \mathrm{L} / \mathrm{V}(20,21)$, which indicated that these variants were absent or were present at a low frequency due to the limitations of Sanger sequencing. This can also be attributed to the lack of regular NAs therapy. In the present study, S53N, I91L, N139K, F221Y and N238H were identified as putative drug resistance mutations; however, their functions remain to be fully elucidated.

The present study demonstrated that $\mathrm{rtF} 221 \mathrm{Y}$ was an independent risk factor for DFS and OS in HCC. rtF221Y was also linked to a higher level of AFP and larger tumor size. To the best of our knowledge, the present study is the first to show that $\mathrm{rtF} 221 \mathrm{Y}$ was associated with HCC in a relatively large cohort of patients. Therefore, $\mathrm{rtF} 221 \mathrm{Y}$ may be used as a potential viral marker for predicting HCC prognosis following surgery. However, previous studies have suggested that $\mathrm{rtF} 221 \mathrm{Y}$ may belong to putative antiviral drug resistance mutations. Mirandola et al (22) and Lee et al (23) reported that $\mathrm{rtF} 221 \mathrm{Y}$ was associated with adefovir dipivoxil (ADV) or lamivudine+ADV experience. Of note, data have shown that one point mutation, L213I, observed in the surface protein, which leads to F221Y and A222T dual mutations in the RT domain of polymerase, in combination with the classical BCP mutations, A1762T/G1764A, are associated with the development of HCC in HBeAg-positive patients (24). In the present study, stratified analysis revealed that patients with the $\mathrm{rFF} 221 \mathrm{Y}$ mutation had lower intrahepatic cccDNA levels $(\mathrm{P}=0.090)$, suggesting viral replication was less active. $\mathrm{rtF} 221$ is located at the nucleic acid binding domain, based on three-dimensional modeling analysis, therefore the rtF221Y mutation is likely to affect the enzyme structure and impair its polymerase activity. Patients with rtF221Y may require regular monitoring and caution when using ADV.

For HBV-associated HCC, a high copy number of HBV DNA is one of the important factors promoting the development of HCC $(25,26)$. RT is important in the process of HBV replication and key mutations may occur during the immune response, affecting the activity of RT. When a guanine was substituted by cytosine at nucleotide 162 in the RT region, which induced the S3 N mutation in HBsAg synchronously, the levels of cccDNA were found to be significantly elevated, compared with those in the wild-type group $(\mathrm{P}=0.004)$. NAs treatment is considered to be an effective method to suppress HBV replication, normalize liver function, reduce $\mathrm{HBV}$-associated $\mathrm{HCC}$ recurrence and improve postoperative survival rates. The occurrence of mutations association with the prognosis of HCC, including rtF221Y, may also decrease when receiving NAs therapy. Several meta-analyses have also revealed that regular antiviral treatment prior to or following 
surgery can significantly prolong OS and decrease recurrence rates (27-29). It is necessary for patients with HBV-associated HCC to adhere to standard antiviral therapy.

The frequency of sR122K, sT140S and sF183 V within the HBsAg between ANTTs and TTs were significantly different, and these mutation sites were all located in the MHR, the primary B-cell epitope of HBV. Of note, the amino acid at position 122 within an antigenic loop determinates the serological HBs subtype. Subtype determinant d have a lysine $(\mathrm{K})$ at this positions, whereas an arginine $(\mathrm{R})$ indicates subtype determinant $\mathrm{y}$. The positive charged amino acid $\mathrm{R}$ at position 122 primarily contributes to electrostatic interaction with negatively charged heparan sulfate proteoglycans at the plasma membrane of hepatocytes during infection (30). However, sR $122 \mathrm{~K}$ is closely associated with immune evasion (31). Patients who harbored R122 K in TTs suffered from larger tumor size and had higher recurrence rates in the present study. Further investigations are required to clarify the association between $\mathrm{R} 122 \mathrm{~K}$ and HCC. There were certain limitations in the present study; a lack of liver biopsies from patients with chronic hepatitis prevented deeper probing into sequence discrepancies in the HBV genome between patients suffering from HCC and chronic hepatitis. Therefore, the exact role of mutations, particularly those located in $\mathrm{RT} / \mathrm{S}$, during the development of HCC requires further investigation. In addition, due to the methodological limitations of Sanger sequencing, limited sensitivity hinders the detection of low abundance mutations (32). Therefore, next-generation sequencing technology is required to dissect viral quasispecies at the RT/S region, to understand the variation of the whole virus population in patients, to analyze minor antiviral resistance mutations and to provide a guide for HBV treatment.

In conclusion, the use of Sanger sequencing of virus derived from TT and ANTT samples revealed two novel substitutions, rtF221Y and sR122K, which were found to be associated with HBV-associated HCC recurrence. In particular, rtF221Y may serve as a viral marker for predicting $\mathrm{HCC}$ prognosis. In view of HBV RT mutations being one of the important factors linked to recurrence, it is necessary for NAs to be timely and selected deliberately for limiting the copy numbers of HBV DNA and preventing drug resistance. This can assist in decreasing recurrence rate and improving postoperative survival rates of patients with HBV-associated HCC.

\section{Acknowledgements}

This study was supported by the China National Key Projects for Infectious Disease (grant no. 2012ZX10002-016), the National Natural Science Foundation of China (grant nos. 81572,072 and 81171664) and the Key Projects of Science and Technology Commission of Shanghai Municipality (grant no. 11JC1416400).

\section{References}

1. Ngamruengphong S and Patel T: Molecular evolution of genetic susceptibility to hepatocellular carcinoma. Dig Dis Sci 59: 986-991, 2014

2. Wu Y, Gan Y, Gao F, Zhao Z, Jin Y, Zhu Y, Sun Z, Wu H, Chen T, Wang J, et al: Novel natural mutations in the hepatitis B virus reverse transcriptase domain associated with hepatocellular carcinoma. PLoS One 9: e94864, 2014.
3. Nischalke HD, Lutz P, Krämer B, Söhne J, Müller T, Rosendahl J, Fischer J, Berg T, Hittatiya K, Fischer HP, et al: A common polymorphism in the NCAN gene is associated with hepatocellular carcinoma in alcoholic liver disease. J Hepatol 61: 1073-1079, 2014.

4. van Bömmel F, Bartens A, Mysickova A, Hofmann J, Krüger DH, Berg T and Edelmann A: Serum hepatitis B virus RNA levels as an early predictor of hepatitis B envelope antigen seroconversion during treatment with polymerase inhibitors. Hepatology 61: 66-76, 2015.

5. Guirgis BS, Abbas RO and Azzazy HM: Hepatitis B virus genotyping: Current methods and clinical implications. Int J Infect Dis 14: e941-e953, 2010.

6. Xie JX, Zhao J, Yin JH, Zhang Q, Pu R, Lu WY, Zhang HW, Wang HY and Cao GW: Association of novel mutations and haplotypes in the preS region of hepatitis B virus with hepatocellular carcinoma. Front Med China 4: 419-429, 2010.

7. Park YM, Jang JW, Yoo SH, Kim SH, Oh IM, Park SJ, Jang YS and Lee SJ: Combinations of eight key mutations in the X/preC region and genomic activity of hepatitis B virus are associated with hepatocellular carcinoma. J Viral Hepat 21: 171-177, 2014.

8. Liu S, Zhang H, Gu C, Yin J, He Y, Xie J and Cao G: Associations between hepatitis B virus mutations and the risk of hepatocellular carcinoma: A meta-analysis. J Natl Cancer Inst 101: 1066-1082, 2009.

9. Chen $\mathrm{CH}$, Changchien $\mathrm{CS}$, Lee CM, Tung WC, Hung $\mathrm{CH}$, $\mathrm{Hu} \mathrm{TH}$, Wang JH, Wang JC and Lu SN: A study on sequence variations in pre-S/surface, $\mathrm{X}$ and enhancer II/core promoter/ precore regions of occult hepatitis $\mathrm{B}$ virus in non-B, non-C hepatocellular carcinoma patients in Taiwan. Int J Cancer 125: 621-629, 2009

10. Zhang D, Ma S, Zhang X, Zhao H, Ding H and Zeng C: Prevalent $\mathrm{HBV}$ point mutations and mutation combinations at $\mathrm{BCP} / \mathrm{preC}$ region and their association with liver disease progression. BMC Infect Dis 10: 271, 2010

11. Yin J, Xie J, Liu S, Zhang H, Han L, Lu W, Shen Q, Xu G, Dong H and Shen J: Association between the various mutations in viral core promoter region to different stages of hepatitis $\mathrm{B}$, ranging of asymptomatic carrier state to hepatocellular carcinoma. Am J Gastroenterol 106: 81-92, 2011.

12. Chen QY, Harrison TJ, Sabin CA, Li GJ, Huang GM, Yang JY, Wang XY, Li H, Liu MH and Fang ZL: The Effect of HBV Genotype C on the Development of HCC Differs Between Wild-Type Viruses and Those With BCP Double Mutations (T(1762)A(1764)). Hepat Mon 14: e16214 2014.

13. Yeh CT, So M, Ng J, Yang HW, Chang ML, Lai MW, Chen TC, Lin CY, Yeh TS and Lee WC: Hepatitis B virus-DNA level and basal core promoter A1762T/G1764A mutation in liver tissue independently predict postoperative survival in hepatocellular carcinoma. Hepatology 52: 1922-1933, 2010.

14. Su CW, Chiou YW, Tsai YH, Teng RD, Chau GY, Lei HJ, Hung HH, Huo TI and Wu JC: The influence of hepatitis b viral load and pre-s deletion mutations on post-operative recurrence of hepatocellular carcinoma and the tertiary preventive effects by anti-viral therapy. PLoS One 8: e66457, 2013.

15. Zhu Y, Jin Y, Cai X, Bai X, Chen M, Chen T, Wang J, Qian G, $\mathrm{Gu} \mathrm{J}$, Li J and Tu H: Hepatitis B virus core protein variations differ in tumor and adjacent nontumor tissues from patients with hepatocellular carcinoma. Intervirology 55: 29-35, 2012.

16. Yan H, Yang Y, Zhang L, Tang G, Wang Y, Xue G, Zhou W and Sun S: Characterization of the genotype and integration patterns of hepatitis B virus in early- and late-onset hepatocellular carcinoma. Hepatology 61: 1821-1831, 2015.

17. Wang $\mathrm{XH}$ and Wang PL: Relationship between mutation on precore region of integrated HBV DNA and p53 gene mutation in hepatocellular carcinoma. Ai Zheng 22: 715-718, 2003 (In Chinese).

18. Chen $\mathrm{CH}$, Changchien CS, Lee CM, Hung CH, Hu TH, Wang JH, Wang JC and Lu SN: Combined mutations in pre-s/surface and core promoter/precore regions of hepatitis B virus increase the risk of hepatocellular carcinoma: A case-control study. J Infect Dis 198: 1634-1642, 2008.

19. Qu LS, Liu TT, Jin F, Guo YM, Chen TY, Ni ZP and Shen XZ: Combined pre-S deletion and core promoter mutations related to hepatocellular carcinoma: A nested case-control study in China. Hepatol Res 41: 54-63, 2011.

20. Li MW, Hou W, Wo JE and Liu KZ: Character of HBV (hepatitis $\mathrm{B}$ virus) polymerase gene rtM204V/I and rtL180M mutation in patients with lamivudine resistance. J Zhejiang Univ Sci B 6: 664-667, 2005. 
21. Liu BM, Li T, Xu J, Li XG, Dong JP, Yan P, Yang JX, Yan L, Gao ZY, Li WP, et al: Characterization of potential antiviral resistance mutations in hepatitis $B$ virus reverse transcriptase sequences in treatment-naïve Chinese patients. Antiviral Res 85: $512-519,2010$.

22. Mirandola S, Sebastiani G, Rossi C, Velo E, Erne EM, Vario A, Tempesta D, Romualdi C, Campagnolo D and Alberti A: Genotype-specific mutations in the polymerase gene of hepatitis $B$ virus potentially associated with resistance to oral antiviral therapy. Antiviral Res 96: 422-429, 2012.

23. Lee HW, Chang HY, Yang SY and Kim HJ: Viral evolutionary changes during tenofovir treatment in a chronic hepatitis B patient with sequential nucleos(t)ide therapy. J Clin Virol 60 313-316, 2014.

24. Datta S, Ghosh A, Dasgupta D, Ghosh A, Roychoudhury S, Roy G, Das S, Das K, Gupta S, Basu K, et al: Novel point and combo-mutations in the genome of hepatitis B virus-genotype D: Characterization and impact on liver disease progression to hepatocellular carcinoma. PLoS One 9: e110012, 2014.

25. Nakamura M, Kanda T, Nakamoto S, Haga Y, Sasaki R, Jiang X, Yasui S, Arai M and Yokosuka O: Reappearance of serum hepatitis B viral DNA in patients with hepatitis B surface antigen seroclearance. Hepatology 62: 1329, 2015.

26. Tseng TC, Liu CJ, Yang HC, Su TH, Wang CC, Chen CL, Kuo SF, Liu CH, Chen PJ, Chen DS and Kao JH: High levels of hepatitis $\mathrm{B}$ surface antigen increase risk of hepatocellular carcinoma in patients with low HBV load. Gastroenterology 142: 1140-1149. e3; quiz e13-4, 2012.
27. Wu CY, Lin JT, Ho HJ, Su CW, Lee TY, Wang SY, Wu C and Wu JC: Association of nucleos(t)ide analogue therapy with reduced risk of hepatocellular carcinoma in patients with chronic hepatitis B: A nationwide cohort study. Gastroenterology 147: 143-151.e5, 2014

28. Wong JS, Wong GL, Tsoi KK, Wong VW, Cheung SY, Chong CN, Wong J, Lee KF, Lai PB and Chan HL: Meta-analysis: The efficacy of anti-viral therapy in prevention of recurrence after curative treatment of chronic hepatitis B-related hepatocellular carcinoma. Aliment Pharmacol Ther 33: 1104-1112, 2011.

29. Sinn DH, Lee J, Goo J, Kim K, Gwak GY, Paik YH, Choi MS, Lee JH, Koh KC, Yoo BC, et al: Hepatocellular carcinoma risk in chronic hepatitis B virus-infected compensated cirrhosis patients with low viral load. Hepatology 62: 694-701, 2015.

30. Glebe D and Bremer CM: The molecular virology of hepatitis B virus. Semin Liver Dis 33: 103-112, 2013.

31. Avellón A and Echevarria JM: Frequency of hepatitis B virus 'a' determinant variants in unselected Spanish chronic carriers. J Med Virol 78: 24-36, 2006.

32. Gong L, Han Y, Chen L, Liu F, Hao P, Sheng J, Li XH, Yu DM, Gong QM, Tian F, et al: Comparison of next-generation sequencing and clone-based sequencing in analysis of hepatitis $\mathrm{B}$ virus reverse transcriptase quasispecies heterogeneity. J Clin Microbiol 51: 4087-4094, 2013. 